\title{
Forståelser av gode overganger og opplevelse av sammenheng mellom barnehage, skole og skolefritidsordning
}

\author{
Hogsnes, Hilde Dehnæes: Phd.-kandidat. Institutt for pedagogikk. Høgskolen i Buskerud og Vestfold. E-post: \\ hilde.d.hogsnes@hbv.no
}

Moser, Thomas: Professor, Institutt for praktisk-estetiske fag, Høgskolen i Buskerud og Vestfold. E-post: thomas.moser@hbv.no

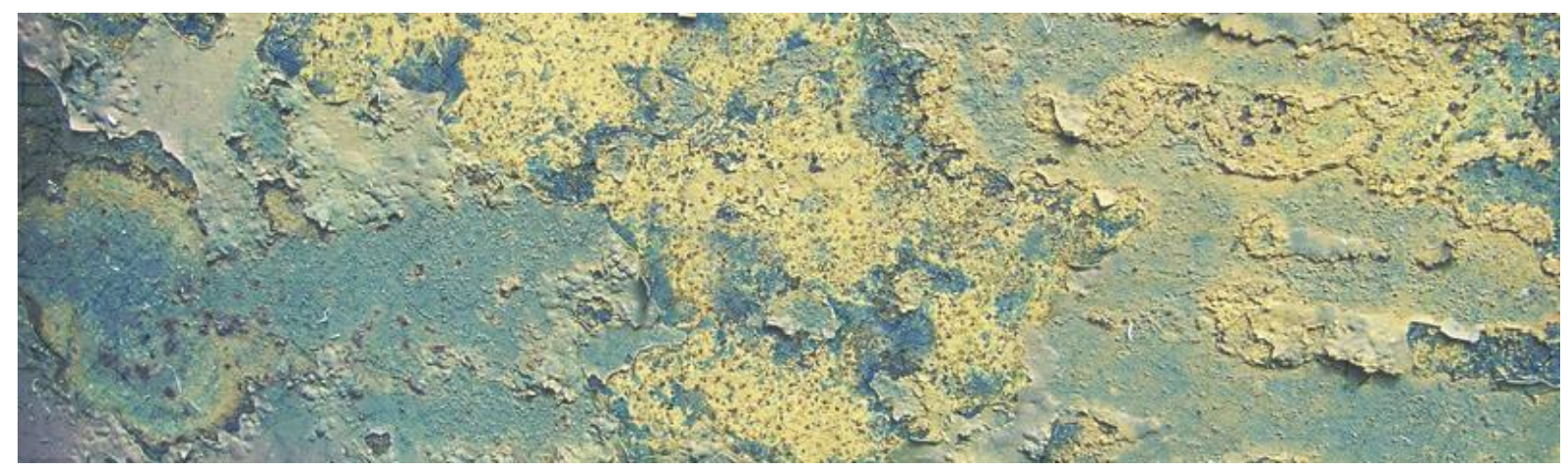

Dette bidraget har bakgrunn i en casestudie av barns overgang og opplevelse av sammenheng mellom barnehage og skole. Samarbeid og sammenheng mellom barnehage og skole er i dag et prioritert område nasjonalt (Kunnskapsdepartementet, 2008-2009) og internasjonalt (OECD, 2001; 2006). Barn skal oppleve sammenheng mellom institusjonene (Kunnskapsdepartementet, 2011). Unders $\varnothing$ kelser viser at de ansatte i barnehage og skole har lite kunnskap om hverandre og at kommunikasjonen mellom dem er mangelfull (Rambøll, 2010; Broström, 2009). Dersom de ansatte har lite kunnskap om de andre institusjonenes tradisjoner, mandat og arbeidsmåter, kan det bidra til å svekke samarbeidet mellom institusjonene. Med dette som bakgrunn undersøkes pedagogiske lederes, førsteklasselæreres og sfo-lederes prioriteringer av tiltak for å gi barn opplevelse av sammenheng i overgangen fra barnehage til skole og skolefritidsordning (sfo). De ulike tiltakene diskuteres i lys av fire former for kontinuitet mellom institusjonene; filosofisk, fysisk, sosial og kommunikasjonsmessig kontinuitet (Broström, 2009; Fabian, 2007). Resultatene viser at det er en særlig utfordrende oppgave å sikre kommunikasjonsmessig kontinuitet. Den kommunikasjonsmessige kontinuiteten er samtidig av avgjørende betydning for barns medvirkning og opplevelse av fysisk, sosial og filosofisk kontinuitet i overgangen fra barnehage til skole og sfo.

Nфkkelord: Overgang; Sammenheng; forståelser; Samarbeid barnehage, skole og Sfo; multimetodologisk 


\section{Innledning}

Problemstillingen for denne casestudien retter seg mot hvordan pedagogiske ledere, førsteklasselærere og sfo-ledere prioriterer tiltak som skal gi barn gode overganger og opplevelse av sammenheng mellom barnehage og skole, slik det blir påkrevd i styringsdokumentene (Kunnskapsdepartementet (KD), 2006; 2011). Sammenheng mellom barnehage og skole fremstår i dag som et prioritert område, også internasjonalt. Organisasjonen for økonomisk samarbeid og utvikling (OECD) understreket allerede i 2001 behovet for en mer helhetlig tenkning rundt sammenhengen mellom institusjonene.

I Norge har institusjonene, barnehage, skole og sfo ulike historier, tradisjoner og mandat (Bjørnestad, 2005; Germeten, 2002). Dette kan bidra til at forventninger om å skape sammenheng forstås på ulike måter. Barnehagen i Norge beskrives gjerne under fellesbetegnelsen nordisk sosialpedagogisk barnehagetradisjon (OECD, 2001; 2006). Den nordiske heldagsbarnehagen kan ses som et eksempel på hvordan man innenfor denne tradisjonen har sett omsorg, lek og læring i sammenheng. Innenfor en europeisk førskoletradisjon kan man i sterkere grad se et organisatorisk skille, der dagen deles opp i en pedagogisk del og en omsorgsdel uten pedagogisk definert innhold.

Til tross for ulike tradisjoner mellom Norden og andre europeiske land, er det også forskjeller innenfor den nordiske tradisjonen, både med hensyn til institusjonenes mandat og barnas alder ved skolestart. Mens barna i Norge starter i 1. klasse ved 6 årsalder, får 6-åringene i Sverige og Danmark sine pedagogiske tilbud i förskole- og børnehaveklasser på skolen. I likhet med at de fleste skolestartere i Norge også begynner i sfo, begynner barna i Sverige og Danmark i fritidshjem. Mens barna i Norge starter opp på sfo i august, 2-3 uker før skolestart, begynner de aller fleste barna i Danmark på fritidshjemmet allerede i mai måned, før skolestart i august. Fritidshjemmet blir dermed en sentral del av overgangen. I motsetning til fritidshjemmene i Sverige og Danmark er sfo i Norge ikke definert som en pedagogisk virksomhet. Sfo beskrives som en institusjon for omsorg, lek, kultur og fritidsaktiviteter (Kirke-, utdannings- og forskningsdepartementet (KUF), 1996-1997), men har verken rammeplan eller læreplan. Utover at rektor er sfo's øverste leder, er det ingen krav til pedagogisk bemanning $\mathrm{i}$ institusjonene. Til tross for at sfo ikke ses som pedagogisk virksomhet utgjør den likevel en relativt stor del av de aller fleste barns hverdag ved skolestart ${ }^{1}$. De fleste som begynner i første klasse begynner også i sfo. I denne artikkelen tar vi dette i betraktning når vi undersøker prioriteringer av tiltak for å gi barn en god overgang og opplevelse av sammenheng mellom barnehage og skole.

Med disse likhetene og ulikhetene som bakteppe tar den foreliggende unders $\varnothing$ kelsen utgangspunkt i nasjonal (Bjørnestad, 2005; Haug, 2013; Rambøll, 2010; Østrem m.fl., 2009) og internasjonal forskning (Brostrøm; 2009; Docket \& Perry, 2007; Fabian, 2007; Margetts \& Kienig, 2013; Peters, 2010) på overgangen fra barnehage til skole. Peters (2010) har lagt fram en oversikt over forskning på overganger mellom barnehage og skole som baserer seg på en overordnet analyse av åtte nasjonale (New Zealand) og internasjonale forskningsoversikter. Her fremkommer som noen av nøkkelfaktorene for gode overganger at barna føler seg hjemme og trives på skolen, gjensidig anerkjennelse av institusjonenes ulike kulturer og relasjoner mellom dem, positive lærerforventninger i skolen, og at skolen bygger videre på barns kunnskap. I hvilken grad det lykkes med overganger er i

\footnotetext{
${ }^{1}$ Mens barnehagens og skolens felles ansvar for samarbeidet fremheves, er skolefritidsordningens (sfo) betydning nedtonet i rammeplan for barnehagen (KD, 2011). Samtidig er det kjent at de fleste barn som begynner i første klasse også tilbringer mye tid i sfo. Tall fra 2007 viste at i overkant av 130000 elever hadde plass i sfo på landsbasis og at dekningsgraden var høyest blant de yngste. To tredjedeler av elevene på 1. trinn benyttet seg av sfo-tilbudet (KD, 2006-2007).
} 
følge Peters (2010), kontekstavhengig, Det finnes ikke én modell som kan betraktes som en universell løsning på alle utfordringene knyttet til overganger.

Ansvaret for iverksettelse av strategier og tiltak knyttet til forventningen om samarbeid mellom barnehage og skole er i stor grad overlatt til den enkelte kommune i Norge. Østrem m.fl. (2009) viser at forventningene forstås på ulike måter i ulike kommuner. Det hevdes at det er gjort lite i Norge for å assistere kommunene i arbeidet med å oppfylle de sentrale føringene (Haug, 2013). Ut fra den drøftete litteraturen synes det påkrevd å få dypere kunnskap om hvordan og på hvilket grunnlag det arbeides med overgang og sammenheng i det pedagogiske feltet. Overgang og sammenheng er begreper som i seg selv kan virke motstridende. De ulike begrepene brukes også ulikt i ulike styringsdokumenter: I Rammeplanen for barnehagen (KD, 2011) brukes begrepene sammenheng og overgang. I læreplanverket for skolen (KD, 2006) benyttes begrepet overgang, mens i forordet til veilederen, Fra eldst til yngst. Samarbeid og sammenheng mellom barnehage og skole (KD, 2008), fokuserer kunnskapsministeren på sammenheng i overgangen. Vår forståelse av sammenheng knyttes her til formuleringen fra Veilederen, til betydningen av å skape sammenheng i overgangen. I denne undersøkelsen anvender vi ulike former for kontinuitet som et teoretisk utgangspunkt for å tilnærme oss det begrepene overgang og sammenheng representerer. Dette utgangspunktet indikerer også at vi retter mer oppmerksomhet mot sammenhengen (kontinuitet) enn mot overgangen (diskontinuitet). Vi ser prioriterte tiltak som skal bidra til at barn opplever sammenheng i relasjon til fire former for kontinuitet slik de er presentert av Broström (2009) og Fabian (2007); Muligheter for opplevelse av kontinuitet ses i lys fysiske, sosiale, filosofiske og kommunikasjonsmessige forhold (Broström, 2009; Fabian, 2007).

\section{Hensikt og forskningsspørsmål}

Med utgangspunkt i de fire kategoriene, fysisk, sosial, filosofisk og kommunikasjonsmessig kontinuitet (Broström, 2009; Fabian, 2007), er studiens hensikt å undersøke hva pedagogiske ledere, førsteklasselærere og sfo-ledere i en kommune vektlegger i arbeidet med overganger og sammenhenger når barn slutter i barnehagen og begynner på skolen og sfo. Forskningsspørsmålet er:

- Hva vektlegger pedagogiske ledere, førsteklasselærere og sfo-ledere i arbeidet med å sikre gode overganger og opplevelse av sammenhenger for barn?

- Hvordan forholder pedagogiske lederes, førsteklasselæreres og sfo-lederes prioriteringer seg til kategoriene fysisk, sosial, filosofisk og kommunikasjonsmessig kontinuitet?

Med fysisk kontinuitet menes sammenhenger mellom fysiske miljø. Barnas møte med skole og sfo vil nødvendigvis innebære brudd i forhold til fysisk miljø. Dagen organiseres på nye måter, i andre rom og de møter nytt leke- og læringsmateriell. Barna vil videre oppleve at det er færre voksne for flere barn (Broström, 2009). Færre voksenpersoner i større barnegrupper kan ha betydning, også for barns opplevelse av sosial kontinuitet. Overgangen fra barnehage til skole og sfo medfører nye sosiale vilkår der barnet opplever en form for identitetsskifte. Barnet går fra å være barnehagebarn til å bli skoleelev og må forholde seg til nye sosiale koder, i form av så vel språk og begreper som regler for adferd. Sosial kontinuitet berører spørsmål som har med relasjoner og identitet å gjøre (Broström, 2009; Fabian, 2007). Samtidig som barna i overgangen vil oppleve nye sosiale vilkår, vil de møte nye krav og forventninger til læring. En vanlig oppfatning er at i skolen dominerer læringen, i barnehagen leken (Broström, 2009; Fabian, 2007). Mens lærere i skolen skal forholde seg til mål for hva barn skal inneha av kompetanse i ulike fag på ulike trinn (KD, 2006), opererer Rammeplan for barnehagens 
innhold og oppgaver (KD, 2011) med prosessmål knyttet til personalets arbeid innenfor ulike fagområder. Disse ulikhetene vil kunne komme til uttrykk i forståelser av lek og læring i institusjonene, noe som Broström (2009) omtaler som filosofisk kontinuitet i overgangen fra barnehage til skole.

Ved opprettelsen av sfo var intensjonen at virksomheten skulle baseres på omsorg, lek, sosial læring og kulturelle aktiviteter (Haug, 1994). Dette er et pedagogisk innhold som står sterkt, også i barnehagen. Til tross for institusjonenes ulike mandat, gjør likhetene mellom barnehage og sfo det interessant å se nærmere på hvordan ikke bare barnehage og skole, men også sfo kan bidra til å gi barn en opplevelse av filosofisk kontinuitet (Broström, 2009; Fabian, 2007). Begrepet filosofisk kontinuitet forstås i dette bidraget i retning pedagogisk filosofi og knyttes her til de pedagogiske og verdimessige forutsetningene for innhold og arbeidsmetoder i institusjonene.

Broström $(2009 ; 2003)$ argumenterer videre for kommunikasjonsmessig kontinuitet og løfter dermed fram betydningen av at de ulike partene har og utveksler kunnskap om og med hverandre. I vår undersøkelse forstås kommunikasjonsmessig kontinuitet som et uttrykk for dialogen mellom de pedagogiske lederne, førsteklasselærerne, sfo-lederne, foreldrene og, ikke minst, dialogen disse gruppene har med barna.

\section{Design og metode}

Denne multimetodisk anlagte casestudien utspringer fra et utviklingssamarbeid mellom en bykommune i Vestfold og Høgskolen i Vestfold, Fakultet for humaniora og utdanningsvitenskap. Den genererte kunnskapen skulle bidra til kvalitetssikring og -utvikling av samarbeidet mellom institusjonene i kommunen.

I følge Thomas (2011) analyserer casestudier personer, hendelser, beslutninger, institusjoner eller andre systemer på en helhetlig måte. Her er forskningsgjenstanden en forekomst av en klasse av fenomener som utgjør en analytisk ramme. Casen er i vårt tilfelle en kommune representert ved et utvalg medarbeidere som representerer relevante delsystemer (barnehage, sfo, skole). Fenomenet kan så sies å være overganger og sammenhenger mellom disse delsystemene. I den foreliggende studien representerer casen altså hva pedagogiske ledere, førsteklasselærere og sfo-ledere i en kommune vektlegger i arbeidet med å sikre gode overganger og opplevelse av sammenhenger for barn når de slutter i barnehagen og begynner på skolen. Gjennom casestudien søker vi kunnskap om et område som muligens vil frembringe temaer og momenter som bør undersøkes videre (Stake, 2005).

En casestudie kan benytte seg av både kvalitative og kvantitative metoder (Stake, 2005; Thomas, 2011). Den valgte multimetodiske tilnærmingen skal ivareta bredde og dybde i kunnskapen som frembringes: I henhold til typologiseringsforslaget for "mixed method designs" fremsatt av Leech og Onwuegbuzie (2009), tilsvarer unders $\varnothing$ kelsen et "partially mixed, sequential and equal status design". Det vil si at kvantitative og kvalitative metoder brukes etter hverandre og at de er like betydningsfulle for besvarelsen av forskningsspørsmålene. En innledende kvantitativ orientert spørreskjemaunders $\varnothing$ kelse skal bidra til å oppnå en bredere oversikt. Funnene fra spørreundersøkelsen skal deretter drøftes og utdypes ved hjelp av fokusgruppeintervjuer.

Wibeck (2000) fremstiller fokusgruppeintervjuet som spesielt godt egnet når en vil undersøke hvordan deltakerne handler, eller sier at de handler, og hvilke begrunnelser og motiver som kan ligge til grunn for disse handlinger. Barnehage, skole og sfo tilhører ulike tradisjoner og har ulike mandater, men har samtidig et felles ansvar for å sikre barn gode overganger og opplevelse av sammenheng mellom institusjonene. Gjennom å dele kunnskap og erfaringer om barns overgang fra barnehagen til 
skole og sfo kan aktørene fra de ulike institusjonene, i intervjusituasjonen reflektere over hvorfor de handler og tenker som de gjør.

\section{Datainnsamling}

Den kvantitative delen av undersøkelsen ble gjennomført ved hjelp av et spørreskjema som omfattet 100 spørsmål, derav 15 med åpne svarmuligheter og resten med lukkete svaralternativer. Skjemaet ble utarbeidet i nært samarbeid med rådgivere for barnehage og skole i den respektive kommunen og omfattet følgende åtte dimensjoner:

- Barns opplevelse av sammenheng i overgangen fra barnehage til skole

- Tiltak som kan bidra til å skape sammenheng for barn

- Samarbeid med barn og foreldre i overgang fra barnehage til skole

- Forståelse for hverandres pedagogiske praksis i barnehage og skole

- Informasjonsoverføring

- Organisatoriske utfordringer for samarbeid

- Opplysninger om respondentens person, utdanning og arbeid

- Opplysninger om institusjonen

Spørreskjemaet ble i flere omganger lagt fram for representanter for målgruppen, i vesentlig grad førskolelærere ${ }^{2}$ og lærere. Disse ble bedt om en fors $\emptyset$ ksvis utfylling av skjemaet. Deltakerne i utprøvingene skulle kommentere uklarheter, identifisere de spørsmålene som var vanskelig å forstå eller som ble oppfattet som flertydig. Innspillene fra disse prøverespondentene ble kontinuerlig tatt med i videreutvikling av skjemaet.

Datagenereringen i den kvalitative delen av undersøkelsen bygger på tre fokusgruppeintervjuer med tre ulike grupper bestående av 4-6 personer og sammensatt av pedagogiske ledere, førsteklasselærere og sfo-ledere. Informantene var kjent med intervjuenes hensikt, som var å utdype forståelsen av utvalgte funn ved hjelp av innledende spørsmål og å gi anledning til å komme med egne betraktninger og refleksjoner. Fokusgruppeintervjuene lå tett opp til det Kvale (1997) kaller halvstrukturert intervju. Intervjuene var strukturerte med tanke på at forskerne sørget for at alle spørsmålene ble belyst. Samtidig bar de preg av å være ustrukturerte gjennom at de ga rom for at informantene også kunne diskutere fritt og stille hverandre spørsmål underveis. Intervjuguiden var avgrenset med hensyn til antall spørsmål og tematikk, men samtidig fleksibel i bruk av spørsmålsform og rekkefølge (Kvale, 1997; Wibeck, 2000, s.71). Fokusgruppeintervjuene tok utgangspunkt i fire konkrete funn fra spørreundersøkelsen og en påstand som ble framlagt for deltakerne med tilhørende spørsmål (se tabell 1).

\footnotetext{
${ }^{2}$ I 2013 ble stillingsbetegnelsen, gjennom revidert Rammeplan for barnehagelærerutdanningen, endret til barnehagelærer. Ettersom våre respondenter har sin utdannelse fra før den tid, benyttes fortsatt betegnelsen førskolelærer.
} 
Tabell 1. Innspill til fokusgruppeintervjuene basert på funn fra spørreskjemaundersøkelsen.

Funn fra spørreskjemaundersøkelsen Sporsmål i fokusgruppeintervju

Både førsteklasselærere, sfo-ledere og pedagogiske ledere ser betydningen av å skape sammenheng og en tydelig overgang når barna slutter i barnehagen og begynner på skolen

Informasjon om enkeltbarn før skolestart vektlegges i stor grad.

Samarbeid mellom barnehage og skole synes å anses som noe viktigere enn samarbeidet med sfo.

Det anses som viktig at "undervisningen bygger på et innhold barna kjenner fra barnehagen" og at "barna møter kjente arbeidsmetoder".

\section{Påstand}

Barnehage og skole har som felles formål å fremme danning og læring. Videre skal alle barn i barnehage og skole sikres rett til danning og medvirkning.
På hvilke områder tenker du at det er viktig at barn opplever sammenheng? Hvordan vil du legge til rette for gode overganger?

Hva tenker du at det er viktig for skolen å få informasjon om vedrørende enkeltbarn?

Hvordan forstår du sfo's betydning for barns opplevelse av sammenheng mellom barnehage og skole?

Hvordan kan førsteklasselærere, pedagogiske ledere og sfo-lederne bidra til dette?

Hvordan kan barnehage og skole fremme danning og læring, og samtidig sikre barn rett til medvirkning i arbeidet med å skape gode overganger og sammenheng mellom barnehage og skole?

Intervjuene ble dokumentert ved hjelp av digital lydopptak og skriftlig logg. To forskere ledet intervjuene. En av dem styrte samtalene, den andre noterte sentrale utsagn og ordskifte i en loggbok.

\section{Undersøkelsesdeltakere}

Målgruppen for denne unders $\varnothing$ kelsen var pedagogiske ledere som arbeidet med de eldste barna (avgangskullet) i barnehagene, lærere i skolene som skulle ta i mot førsteklassingene og lederne for skolefritidsordningene ved skolene (sfo-ledere). I kommunen der unders $\emptyset$ kelsen ble gjennomført, benytter nærmere $92 \%$ av skolestarterne seg av sfo-tilbudet. Skolefritidstilbudet er, gjennom en sfoleder, representert i kommunens referansegruppe for samarbeid mellom barnehage, skole og sfo.

I alt responderte 44 personer på 75 utsendte spørreskjemaer, 37 kvinner og fire menn. To respondenter har ikke besvart spørsmålene om kjønn, utdanning og stilling. 29 var førskolelærere, åtte var lærere og fem hadde annen pedagogisk utdanning. 15 respondenter arbeidet som lærere, 21 som pedagogiske ledere og seks som sfo-ledere. Svarprosenten for spørreskjemaundersøkelsen lå på $59 \%$. Deltakerne i studiens kvalitative del, syv pedagogiske ledere, fem førsteklasselærere og to sfo-ledere, ble rekruttert gjennom selvseleksjon.

\section{Undersøkelsesgjennomføring}

Spørreskjemaundersøkelsen ble gjennomført sent på våren 2011, den kvantitative datanalysen foregikk høsten 2011. Fokusgruppeintervjuene ble gjennomført i januar 2012, med transkribering og analyse vinteren og våren 2012. Spørreskjemaet ble sendt til alle barnehager og skoler i kommunen gjennom 
kommunens interne postsystem. Virksomhetslederne var de primære adressatene og skulle formidle skjemaene videre til de potensielle unders $\emptyset$ kelsesdeltakerne, det vil si personalet i barnehage som arbeidet med 5-åringene, og personalet i skole og sfo som ved neste anledning skulle ta i mot 1.klassingene.

Rekrutteringen av informantene til den kvalitative delen av undersøkelsen foregikk gjennom selvseleksjon. Informantene kunne i forbindelse med innsendelsen av det utfylte spørreskjemaet fylle ut et skjema hvor de erklærte seg villig til å delta i fokusgruppeintervjuene. Dette ble organisert på en slik måte at det ikke var mulig å koble denne påmeldingen til de utfylte spørreskjemaene. I forkant av intervjuene fikk informantene, i tillegg til intervjuguiden, tilsendt et notat som inneholdt en oppsummering av resultater fra den kvantitative undersøkelsen (se tabell 1). Notatet fra spørreundersøkelsen fungerte dermed både som utgangspunkt for utarbeidelse av intervjueguiden og som stimulusmateriale i intervjuene. Hensikten var å stille spørsmål for videre refleksjon (Wibeck, 2000).

\section{Dataanalyse}

Besvarelsene av spørreskjemaet ble manuelt overført i en datamatrise for videre statistisk behandling (IBMSPSS 19). Deskriptive metoder ble brukt for å analysere svarene på delgruppe- og totalgruppenivå. To av tre gruppeintervjuer ble transkribert, og resulterte i 37 sider tekst. For det tredje forelå ingen lydopptak på grunn av teknisk svikt, og det inngikk derfor kun en skriftlig logg på 5 sider i den videre analysen. Etter transkribering ble den videre analysen gjennomført i tråd med Braun og Clarke's (2006) anbefalinger for en tematisk analyse. Braun og Clarke løfter fram betydningen av å synliggjøre valgene $\mathrm{i}$ analyseprosessen og presenterer en fremgangsmåte $\mathrm{i}$ arbeidet med analyse av et samlet datamateriale. Analysearbeidet bestod av lesing og relesing av data, deretter en koding av innholdsmessige enheter, identifisering og revurdering av temaer, som ble avsluttet med definisjon og redefinering av temaer og undertemaer. Gjennom denne prosessen var det ledende prinsippet å være tett på det empiriske materialet og å beskrive arbeidsskrittene slik at analysen ble så transparent som mulig (Braun \& Clarke, 2006; Maxwell, 2005).

Etter transkribering, lesing og relesing ble resultatene av spørre- og intervjuundersøkelsen først kategorisert på grunnlag av kategoriene fysisk, sosial, filosofisk og kommunikasjonsmessig kontinuitet (Broström, 2009; Fabian, 2007). Underveis i analysearbeidet ble det avdekket nye undertemaer som i den foreliggende artikkelen legges til grunn for resultatfremstillingen. Analysene går fra det beskrivende, der datamaterialet blir sortert og organisert for å avdekke vesentlige mønstre, til det fortolkende der mønstrene blir drøftet i lyset av teori og tidligere undersøkelser og følger dermed Braun og Clarke's (2006) forståelse av tematisk analyse som en prosess fra identifisering, til analyse og formidling av forskningsdata.

\section{Vurdering av undersøkelsens kvalitet}

Casestudien er basert på et utviklingsprosjekt som ble gjennomført i kun én kommune. Den genererte kunnskapen har derfor kun begrenset gyldighet. Resultatene gjelder først og fremst for den ene kommunen, men kan eventuelt også ha en viss relevans for strukturelt sammenlignbare kommuner. Gjennom at spørsmålsformuleringene retter seg direkte mot problemstilling og forskningsspørsmål kan man gå ut fra en viss grad av umiddelbar gyldighet av funnene (face-validity). Informantene og respondentene er velutdannet og har relevant erfaring, kunnskap og kompetanse når det gjelder 
studiens problemstilling. Siden deltakelsen i studien var frivillig og informantene selv meldte sin interesse for å delta i intervjudelen kan man gå ut fra at de er opptatt av problemstillingen og at deres respons og bidrag er troverdige.

Piloteringen av spørreskjemaet ga indikasjon på at respondentene hadde en relativ enhetlig oppfatning og vurdering av spørsmålene og at det ikke var særlig vanskelig hverken å forholde seg til spørsmålene eller å svare ved hjelp av de gitte svarkategoriene. Vurderingen av intervjusituasjonen tyder på at sentrale begrep (for eksempel overgang; sammenheng) ble forstått på en noenlunde overensstemmende måte av informantene og at den begrepsmessige validiteten derfor bør være tilfredsstillende ivaretatt.

Analyseprosessen fors $\varnothing \mathrm{kte}$, som tidligere fremstilt, å følge en konkret analysemodell som har til hensikt å skape en troverdig og transparent kunnskapsgenerering. At fokusgruppeintervjuene har forholdt seg direkte til funnene fra spørreskjemaundersøkelsen kan også ses på som et bidrag til validering av funnene og fortolkninger. Informantene kom ikke med fortolkninger som var grunnleggende motstridende til forskernes forståelse. Ut fra undersøkelsens kontekst mener vi altså at resultatene er pålitelig og troverdig når det gjelder den konkrete kommunen og at de kan ha en viss relevans for andre bykommuner med en lignede barnehage- og skolestruktur. Likevel bør en være varsom med generaliseringer.

\section{Resultater og diskusjon}

Fordi de to metodene for kunnskapsgenerering i denne studien var innholdsmessig nært knyttet til hverandre, presenteres resultatene fra spørreundersøkelsen og fokusgruppeintervjuene samlet. Denne felles resultatfremstillingen er en konsekvens av et multimetodisk design. Grunnlaget for strukturen i resultatframstillingen er ikke hvilke metoder som har frembragt dataene, men heller de tematiske enhetene. Disse belyses og diskuteres samlet for hvert tema ut fra funnene fra spørreskjemaet og fra fokusgruppeintervjuet, før det gås videre til neste temaet.

\section{Samarbeid, sammenheng og overgang}

Vi vil først se nærmere på hvordan vårt utvalg av pedagogiske ledere, sfo-ledere og førsteklasselærere vektlegger betydningen av at barn opplever en tydelig overgang og sammenheng når de slutter $\mathrm{i}$ barnehagen og begynner på skolen (se tabell 2).

Tabell 2. Betydning av tydelig overgang og opplevelse av sammenheng $(n=44)$.

\begin{tabular}{|c|c|c|c|c|c|c|c|c|}
\hline \multirow[b]{2}{*}{ Viktighet av tydelig overgang } & \multicolumn{2}{|c|}{ ikke viktig } & \multicolumn{2}{|c|}{ mindre viktig } & \multicolumn{2}{|c|}{ ganske viktig } & \multicolumn{2}{|c|}{ meget viktig } \\
\hline & 0 & $0,0 \%$ & 3 & $6,8 \%$ & 14 & $31,8 \%$ & 27 & $61,4 \%$ \\
\hline $\begin{array}{l}\text { Viktighet av opplevelse av } \\
\text { sammenheng }\end{array}$ & 0 & $0,0 \%$ & 4 & $9,1 \%$ & 15 & $34,1 \%$ & 25 & $56,8 \%$ \\
\hline
\end{tabular}

Alle grupper, så vel pedagogiske ledere, som førsteklasselærere og sfo-ledere, ser betydningen av at barn opplever både sammenheng og en tydelig overgang når de slutter i barnehagen og begynner på skolen. Barns overgang fra barnehage til skole vil nødvendigvis måtte representere noen brudd, noe 
som også synes å være i tråd med barns forventninger. Barn ønsker seg "noe nytt" når de begynner på skolen (Dunlop \& Fabian, 2007). Det interessante i denne sammenheng er på hvilke områder de ulike aktørene mener det er vesentlig med opplevelse av brudd og hvor det synes å være viktig å skape kontinuitet.

\section{Betydningen av fysisk kontinuitet}

Å la barna bli kjent med skolens og sfo's fysiske miljø kan bidra til trygghet og gi barn en opplevelse av kontinuitet i overgangen (Broström, 2009; Fabian 2007). I spørreundersøkelsen understreker respondentene betydningen av fysisk kontinuitet i overgangen fra barnehage til skole og sfo (se tabell $3)$.

Tabell 3. Betydning av at barna bes $\varnothing$ ker skole og sfo før skolestart $(n=42-44)$.

\begin{tabular}{|c|c|c|c|c|c|c|c|c|}
\hline & \multicolumn{2}{|c|}{ ikke viktig } & \multicolumn{2}{|c|}{ mindre viktig } & \multicolumn{2}{|c|}{ ganske viktig } & \multicolumn{2}{|c|}{ meget viktig } \\
\hline $\begin{array}{l}\text { Viktighet av at barna besøker } \\
\text { skolen }\end{array}$ & 0 & $0,0 \%$ & 2 & $4,5 \%$ & 7 & $15,9 \%$ & 35 & $79,5 \%$ \\
\hline $\begin{array}{l}\text { Viktighet av at barna besøker } \\
\text { sfo }\end{array}$ & 0 & $0,0 \%$ & 3 & $6,8 \%$ & 13 & $29,5 \%$ & 28 & $63,6 \%$ \\
\hline $\begin{array}{l}\text { Viktigheten av at skolen } \\
\text { inviterer alle barn til } \\
\text { førskoledager }\end{array}$ & 0 & $0,0 \%$ & 1 & $2,3 \%$ & 3 & $6,8 \%$ & 40 & $90,9 \%$ \\
\hline $\begin{array}{l}\text { Viktigheten av at barna i bhg } \\
\text { og skole har gjort noe } \\
\text { sammen før skolestart }{ }^{1)}\end{array}$ & 3 & $7,0 \%$ & 8 & $18,6 \%$ & 13 & $30,2 \%$ & 18 & $41,9 \%$ \\
\hline
\end{tabular}

Et stort flertall i alle grupper legger vekt på at barna får besøke både skole og sfo før skolestart, og det ses som viktig at barna inviteres til førskoledager på skolen. Videre vurderes det som betydningsfullt at felles aktiviteter mellom barnehagebarn og skoleelever legges til skolen. Å besøke skolen før skolestart ble av alle grupper ansett som noe viktigere enn å besøke sfo. I fokusgruppeintervjuene kommer imidlertid sfo's betydning for barns opplevelse av fysisk kontinuitet tydeligere fram. En førsteklasselærer sier om sfo:

... jeg tenker at sfo gjør en kjempejobb, for det er jo de som møter barna først. Det er de som tar seg av innkjфringen, det praktiske rundt skolebygget, toaletter og så videre. Så sfo er kjempeviktig oppe i det hele...

Ettersom sfo møter barna først har de, i følge førsteklasselærere og sfo-ledere selv, en viktig oppgave i “å trygge” barn før skolestart. Ved alle skolene som var representert i intervjuene, ble foreldre oppfordret til å la barna starte på sfo i god tid før skolestart. 
Begrepene overgang og sammenheng gjenspeiler anbefalinger i Rammeplanen for barnehagen (KD, 2011) om at barn bør oppleve både likheter og ulikheter mellom institusjonene. Der likheter mellom institusjonene kan representere sammenhenger eller kontinuitet, kan ulikheter representere overganger eller brudd. En pedagogisk leder belyser betydningen av likheter mellom barnehage og sfo:

"Per" gleder seg til sfo hver dag, for det er mest likt barnehagen. Det er også flere voksne der tror jeg. Det varierer selvfølgelig litt, men der er de veldig kjente, og han er jo lengre der enn han er på skolen. ... Sfo er liksom kongen, for det er mest likt barnehagen. Det har vi også fått tilbakemelding på fra de som gikk ut i fjor og kom på bes $\phi k$ innimellom. De sier at sfo er best. Skolen er så mye jobbing. Det er naturlig, men der virker det som om de er veldig trygge ... og der har de jo fast plass.

Likhetene som skisseres kan knyttes til likheter i fysiske miljø mellom barnehage og sfo. Det er flere voksne, barna har faste plasser og dagens organisering er, sammenlignet med skolen, mer lik barnehagens. Sett i et historisk perspektiv har også barnehage og sfo noen felles trekk knyttet til fysiske miljø. Historisk sett har både barnehage og sfo hatt en supplerende funksjon, med hjemmet som forbilde (Jansen, 2000; Lidèn, 1994). Til tross for at barnehagen, i motsetning til sfo, defineres som en pedagogisk virksomhet i Norge, er det i stor grad tilrettelagt for lek og "hverdagsaktiviteter" i begge institusjonene. Bjørnestad (2005) antyder at det i nyere tid også har skjedd en endring hvor "klasserommene har fått en karakter av hybridisering, hvor det er en blanding av både skole og barnehage" (s. 388). Dette var i 2005 og et relevant spørsmål i dag er hvilke endringer som kan ha skjedd med klasserommene etter kunnskapsløftet (KD, 2006). I følge Haug (2013) er det for eksempel blitt mindre rom for lek.

Betydningen av fysisk kontinuitet underbygges også i undersøkelser der barna selv har fått uttale seg. I sine beskrivelser av egne forventninger til skolen forholder barna seg gjerne til det de vet om fysisk miljø; om rom, materiell og organisering av tid (Eide og Winger, 1994; Hogsnes, 2010). Det fysiske miljø barna møter i skole og sfo forteller barna noe om hva de har i vente, om hva de vil oppleve av likheter og ulikheter, sammenhenger og brudd, når de begynner på skolen. Det "praktiske", som våre informanter hevder at sfo "tar seg av", kan ha stor betydning for barn ved skolestart. Barn er opptatte av skolebygget, at de skal klare å finne veien til klasserommet, toalettet og garderoben (Broström, 2003; Peters, 2010). Å møte skolens og sfo's fysiske miljø kan bidra til det alle informantene i dybdeintervjuene var mest opptatte av; å skape trygghet.

\section{Betydningen av sosial kontinuitet}

I situasjoner med store forandringer søker mennesker en form for kontinuitet. Det er lettere å håndtere nye krav og forventninger når man har "en sikker base" av venner (Broström, 2003, s. 60).

Spørreundersøkelsen vår viser at alle grupper, både pedagogiske ledere, sfo-ledere og førsteklasselærere, vektlegger tiltak som skal bidra til at barn får oppleve sosial kontinuitet; som at barna får beholde kontakt med venner når de begynner på skolen (tabell 4). 
Tabell 4. Betydning av at barna opprettholder kontakt med venner fra barnehagen $(n=42)$.

\begin{tabular}{|c|c|c|c|c|c|c|c|c|}
\hline & \multicolumn{2}{|c|}{ ikke viktig } & mindre viktig & \multicolumn{2}{|c|}{ ganske viktig } & \multicolumn{2}{|c|}{ meget viktig } & usikker \\
\hline $\begin{array}{l}\text { Viktighet av at barna } \\
\text { holder kontakt med } \\
\text { barnehagevenner }\end{array}$ & 0 & $0,0 \%$ & $5 \quad 11,9 \%$ & 19 & $45,2 \%$ & 17 & $40,5 \%$ & $12,4 \%$ \\
\hline
\end{tabular}

\section{Betydningen av sosial kontinuitet i form av vennskap}

At vennskap er viktig for barn, bekreftes av undersøkelser der barn selv har fătt uttale seg (Broström, 2003; 2002; OECD, 2006; Søbstad, 2002). I følge våre respondenter bør det legges til rette for sosial kontinuitet i overgangen både gjennom ivaretakelse av eksisterende vennskap og etablering av nye vennskapsrelasjoner mellom barn. Respondentene ser det som viktig både at barna inviteres tilbake til barnehagen etter skolestart og at barn i barnehage og skole møtes og gjør noe sammen før skolestart.

Også i fokusgruppeintervjuene kommer det fram en vektlegging av tiltak som styrker vennskap. Barn som skal til samme skole, kan komme fra små og store barnehager. Noen av førsteklasselærerne er opptatte av at de ansatte i store barnehager samarbeider på tvers av baser og avdelinger for etablering av gode vennskapsrelasjoner mellom barn før skolestart. I enkelte skolekretser er det også etablert samarbeid på tvers av barnehager, der barn som skal begynne på samme skole, møtes i felles aktiviteter og blir kjent med hverandre før skolestart. Dette kan være et viktig tiltak, særlig for barn som går i kommunens mindre barnehager.

Samtidig som at vennskap var et prioritert område kom mulige motsigelser til uttrykk i intervjuene. Det ble hevdet at foreldre er for opptatte av hvem barnet kommer i klasse med. En førsteklasselærer sier.

Foreldre er jo opptatte av hvem som er $i$ klassen, at barna får gå sammen med barn de kjenner og er venner med. Det er problematisk. Barna blir fort kjent med nye. De tilpasser seg.

Vi finner ytringen interessant ettersom den står i en viss kontrast til betydningen av at barn får beholde kontakt med barnehagevenner. Det gis inntrykk av at barn i større grad forventes å etablere nye vennskapsrelasjoner når de begynner på skolen. Dette kan forstås som at barnet forventes å tilpasse seg skolen, fremfor at skolen tilpasser seg barnas behov for sosial kontinuitet. Eksempelet kan være en illustrasjon på det Broström (2002, s. 9) beskriver som behovet for mer "børneparate skoler", at skolen i høyere grad må kunne innta et barneperspektiv og tilpasse seg barnas væremåte. Broström fremhever også betydningen av mer "skoleparate barnehager", at barnehagen i større grad må kunne orientere seg mot det som skjer i skolen. "Å gjøre noe sammen med elever på skolen før skolestart", et tiltak som ble ansett som viktig av alle grupper i undersøkelsen, kan være en slik orientering. At barnehagebarna får bli kjent med eldre elever på skolen vil kunne bidra til opplevelse av sosial kontinuitet.

Et spørsmål vi stilte i notatet og i intervjuguiden var knyttet til sfo's rolle i samarbeidet. Man kunne anta at sfo, en institusjon for omsorg, lek, kultur og fritidsaktiviteter (KUF, 1996-1997), er av betydning for barns opplevelse av sosial kontinuitet. Ut ifra svarene fra spørreundersøkelsen kunne det imidlertid synes som om både pedagogiske ledere, førsteklasselærere og sfo-ledere selv ser sfo som av mindre betydning. Sfo's betydning i samarbeidet løftes imidlertid fram i samtlige intervjuer. Den betydning som løftes fram spesielt, er at sfo gir barn anledning til å etablere gode relasjoner før 
skolestart. Dette kan ses i sammenheng med andre resultater fra spørreundersøkelsen; at alle grupper så på barns mulighet for ivaretakelse og etablering av vennskap som spesielt viktig.

\section{Betydningen av sosial kontinuitet i barn-voksen- relasjoner}

En undersøkelse viser at det kan være viktig for barn å ha med en kjent pedagog i overgangen fra barnehage til skole (OECD, 2006, s. 69). Vi ønsket å se nærmere på vektleggingen av kontinuitet i barn-voksen relasjonen i overgangen.

Som nevnt over blir sfo' $\mathrm{s}$ betydning noe nedtonet når det gjelder sosial kontinuitet $\mathrm{i}$ spørreundersøkelsen. Eksempelvis tilskrives førsteklasselærere større betydning i møtet med barna i barnehagen før skolestart enn sfo-leder (se tabell 5).

Tabell 5. Betydning av at førsteklasselærer og sfo-leder møter barna i barnehagen før skolestart $(\mathrm{n}=44 / 43)$.

\begin{tabular}{|c|c|c|c|c|c|c|c|c|}
\hline & \multicolumn{2}{|c|}{ ikke viktig } & \multicolumn{2}{|c|}{ mindre viktig } & \multicolumn{2}{|c|}{ ganske viktig } & \multicolumn{2}{|c|}{ meget viktig } \\
\hline $\begin{array}{l}\text { førsteklasselærer møter barna } \\
\text { i barnehagen }\end{array}$ & 3 & $6,8 \%$ & 14 & $31,8 \%$ & 13 & $29,5 \%$ & 14 & $31,8 \%$ \\
\hline lærer & 2 & $13,3 \%$ & 7 & $46,7 \%$ & 2 & $13,3 \%$ & 4 & $26,7 \%$ \\
\hline ped-leder & 1 & $4,8 \%$ & 3 & $14,3 \%$ & 9 & $42,9 \%$ & 8 & $38,1 \%$ \\
\hline sfo-leder & 0 & $0,0 \%$ & 3 & $50,0 \%$ & 2 & $33,3 \%$ & 1 & $16,7 \%$ \\
\hline $\begin{array}{l}\text { Viktighet av sfo-leder møter } \\
\text { barna i barnehagen }\end{array}$ & 5 & $11,6 \%$ & 17 & $39,5 \%$ & 11 & $25,6 \%$ & 10 & $23,3 \%$ \\
\hline lærer & 3 & $20,0 \%$ & 9 & $60,0 \%$ & 0 & $0,0 \%$ & 3 & $20,0 \%$ \\
\hline ped-leder & 2 & $10,0 \%$ & 3 & $15,0 \%$ & 9 & $45,0 \%$ & 6 & $30,0 \%$ \\
\hline sfo-leder & 0 & $0,0 \%$ & 3 & $50,0 \%$ & 2 & $33,3 \%$ & 1 & $16,7 \%$ \\
\hline
\end{tabular}

For to respondenter foreligger det ingen informasjon om hva de arbeider som (lærer; sfo-leder; ped-leder).

Det er de pedagogiske lederne som i størst grad ser betydningen av at førsteklasselærer møter barna i barnehagen før skolestart, mens de fleste av førsteklasselærerne og $50 \%$ av sfo-lederne ser et slikt tiltak som mindre viktig. Dette kan tolkes som at de pedagogiske lederne er mer opptatt av barnvoksen-relasjonen i overgangen enn førsteklasselærerne og sfo-lederne er. De ulike prioriteringene kan ha sammenheng med at barnehagen har yngre barn og at barn-voksenrelasjonen prioriteres i stor grad, som i overgangen fra hjem til barnehage. Det kan videre ses i sammenheng med færre voksne på et større antall barn i skolen og betydningen av at barn hjelper barn ved skolestart.

En kunnskapsoversikt fra Sverige viser at nær kontakt mellom barn og voksne i barnehagen er positivt for barns selvoppfatning, selvstendighet og opplevelse av mestring i skolen (Birch \& Ladd, 1998; Hamre \& Pianta, 2001 i Skolverket, 2010, s. 98). Resultatene kan, slik vi ser det, underbygge betydningen av sosial kontinuitet, også i overgang fra barnehage til skole og sfo. I Danmark, der barna begynner i fritidshjemmet på våren før skolestart, møter de en kjent pedagog når de starter på skolen gjennom at fritidspedagogen også har timer i børnehaveklassen. Vi vil anta at sfo, også i Norge, kan spille en viktig rolle $\mathrm{i}$ arbeidet med å skape gode relasjoner og sosial kontinuitet $\mathrm{i}$ overgangen. Betydningen av gode relasjoner må vektlegges. 


\section{Betydningen av filosofisk kontinuitet}

Broström (2009) og Fabian (2007) knytter filosofisk kontinuitet til lek og læring i institusjonene. Når vi i spørreunders $\emptyset$ kelsen unders $\varnothing$ ker de ulike aktørenes vektlegging av filosofisk kontinuitet, knytter vi denne form for kontinuitet til innhold og arbeidsmetoder. Et flertall av respondentene anser det som ganske eller meget viktig at barn møter kjente arbeidsmetoder $(81,4 \%)$ og at undervisningen bygger på et kjent innhold $(63,4 \%)$ (se tabell 6).

Tabell 6. Betydning av at barna møter kjente arbeidsmetoder og innhold i skolen $(n=42)$.

\begin{tabular}{|c|c|c|c|c|c|c|c|c|c|c|}
\hline \multirow[b]{2}{*}{$\begin{array}{l}\text { Barna møter kjente } \\
\text { arbeidsmåter i skolen }\end{array}$} & \multicolumn{2}{|c|}{ ikke viktig } & \multicolumn{2}{|c|}{ mindre viktig } & \multicolumn{2}{|c|}{ ganske viktig } & \multicolumn{2}{|c|}{ meget viktig } & \multicolumn{2}{|c|}{ usikker } \\
\hline & 1 & $2,3 \%$ & 6 & $14,0 \%$ & 22 & $51,2 \%$ & 13 & $30,2 \%$ & 1 & $2,3 \%$ \\
\hline $\begin{array}{l}\text { Undervisningen } \\
\text { bygger på innhold som } \\
\text { barna kjenner fra } \\
\text { barnehagen }\end{array}$ & 2 & $4,9 \%$ & 10 & $24,4 \%$ & 20 & $48,8 \%$ & 6 & $14,6 \%$ & 3 & $7,3 \%$ \\
\hline
\end{tabular}

Innhold og arbeidsmetoder kan knyttes til læringens hva og hvordan i barnehage, skole og sfo Når det gjelder disse aspektene frembragte fokusgruppeintervjuene interessante funn.

\section{Ulike tilnarminger til lek og laring i barnehage og skole}

Både barnehage og sfo kan sies å ha en prosessorientert tilnærming til læring. Læringen tar utgangspunkt i barns erfaringer og interesser. En forskningsrapport (Johansson \& Pramling Samulesson, 2003) viser at barnehagens pedagogikk retter seg mest mot hvordan barn lærer, mindre mot hva de lærer. I skolen kan det forholde seg annerledes. Det blir hevdet at fremfor å la elevenes interesser, erfaringer og spørsmål styre undervisningen, blir politiske beslutninger, et "gitt" innhold, diagnoser, prøver og tester styrende for arbeidet (Bergöö, 2009 i Skolverket, 2010, s. 136).

Beskrivelsene av det pedagogiske arbeidet i barnehage og skole kan leses som en oppmuntring til større bevissthet rundt innhold, mot læringens hva i barnehagen, og mot læringens hvordan, mot barns erfaringer og interesser, i skolen. De pedagogiske lederne i barnehagen er sammen med barna om et innhold. De er ikke sammen bare for å være sammen. De er sammen om noe (Broström, 2012).

Relevante spørsmål i denne sammenheng er hva barnehagen tilbyr barn i lek og felles skoleforberedende aktiviteter og hvordan dette kan ivaretas i skolen.

Ut ifra våre informanters uttalelser, kan det sies at lekpregede aktiviteter har ulik posisjon i barnehage, skole og sfo. En førsteklasselærer sier:

Vi har jo samling, vi synger, har språkleker og barn forteller. Vi bruker en halv time. Men så går de $i$ gang.

Uttalelsen kan forstås som at førsteklasselærere ser samling med språkleker som noe som skjer før de er "i gang" med det som egentlig skal skje på skolen. Leken i skolen omtales i hovedsak som noe som foregår i friminuttene og på sfo. I Sverige har forskere som analyserte virksomheten $\mathrm{i}$ førskoleklassene, vært tydelige på at barna møter en arbeids- og undervisningsform i skolen som i større grad går ut på "å gjøre ting riktig" (Persson \& Vetenskapsrådet, 2008, s. 91). En tenkning om "å 
gjøre ting riktig" blir belyst, også i våre intervjuer. Et eksempel er knyttet til et spørsmål fra en pedagogisk leder til førsteklasselærer. Spørsmålet handler om hvordan barn skal lære å skrive bokstaver "riktig", og en av lærerne svarer som følger:

Det må ikke bli for skolsk heller ... Jeg tenker språkleker, masse litteratur. La dem bade $i$ bøker og la de ble nysgjerrig på språk og bokstaver. Og, i matematikken, la de utforske ting og snakke om disse før-matematiske begrepene; kort-lang, stor-liten, alle de tingene der. Det er så viktig. Ikke la de sitte å skrive tall og bokstaver. Jeg vet ikke om dere gjør det, men det er ting de kan ta etter hvert. Det er ikke det første vi gjør på skolen heller. Det er mange barnehager som tror at de skal kunne tall og bokstaver når de kommer til skolen. Det trenger de ikke.

Når pedagogiske ledere i barnehagen blir for opptatte av "å gjøre ting riktig", kan det tolkes som at pedagogiske ledere, i den hensikt å forberede barn til skolestart, søker å tilpasse seg skolen og skolens arbeidsmåter. I sitatet over fremkommer betydningen av at barnehagen har kunnskap om det barna vil møte ved skolestart. Førsteklasselærere er mer opptatt av at barn i barnehagen skal få delta i språkleker og "bade i bøker" enn å lære å skrive "riktig". En slik tilnærming til språk- og leseutvikling støttes av forskning utført av Jensen, Hansen og Broström (2013). Lesing og samtaler om bøker, etterfulgt av rollespill og tegneaktiviteter støtter barns språkutvikling og leseferdigheter. Å stimulere til nysgjerrighet rundt tall og bokstaver i barnehagen kan knyttes til hverdagsaktiviteter, som å skrive handlelister eller til lek, som doktorlek der "pasienter" får resepter. En slik tilnærming gir barn mer rom for å reflektere og bruke sin fantasi. Mulighetene i hverdagen er mange, og aktivitetene må oppleves meningsfulle for barnet i skolen så vel som i barnehagen. Jensen, Hansen og Broström (2013) knytter utvikling av språklig kompetanse til sosial kompetanse og "learning to live together."

\section{Ulike tilnarminger til lek og laring $i$ barnehage og sfo}

Lek og fritid ses som viktig av våre informanter, og det synes som at alle grupper i undersøkelsen er opptatte av å ivareta "den frie leken" i barnehage og sfo. Samtidig kan arbeidet som beskrives av pedagogiske ledere og sfo-ledere selv ses i sammenheng med mer voksenstyrt skoleforberedelse. En sfo-leder sier:

Sfo starter tidligere på høsten. Vi bruker disse ukene på å forberede barna på skolestart. Vi besøker klasserommene og legger opp dagene som om det var skole. Vi ser dette som viktig før flagget går til topps første skoledag.

Lignende eksempler på lek som skoleforberedelse kan ses i pedagogiske lederes beskrivelser av leken i barnehagen. Pedagogiske ledere er opptatte av å ivareta det de kaller lek på "barnas premisser". Samtidig kommer tanken om lek som skoleforberedelse til uttrykk i intervjuene. En pedagogisk leder sier:

Leken er viktig, for eksempel leker barna skole. Her ligger det muligheter for å $\emptyset$ ve på å rekke opp hånda, vente på tur og lignende ...

Flere undersøkelser viser at barn øves opp på å rekke opp hånda i barnehagen (se Rambøll, 2010). Gruppeoppgaver der barna må rekke opp hånda, er samtidig noe barn selv karakteriserer som "kjedelig og dumt" (Bratterud, Sandseter \& Seland, 2012, s. 58). Å legge til rette for skole-lek i barnehagen kan imidlertid være god form for skoleforberedelse. Ettersom barn gjerne selv tar initiativ til lek rundt noe de er opptatte av, leker de gjerne skole i barnehagen. Observasjoner av barnas lek vil kunne fortelle 
pedagogen noe om hva barna vet og tenker om innhold og arbeidsmåter i skole og sfo. Leken kan fortelle pedagogen noe om hva som, sammen med barna, kan være verdt å unders $\varnothing$ ke nærmere.

Et interessant funn i vår undersøkelse er at, til tross for at informantene understreker betydningen av å ivareta den frie leken er denne lite omtalt i vårt materiale. Dette kan ha sammenheng med at informantene var innstilte på å snakke om "tiltak" som kunne bidra til å skape gode overganger og sammenheng for barn. Samtidig er det en tankevekker. Sfo representerer, slik våre informanter har understreket, oftest barns første møte med skolen. Noen pedagogiske ledere og førsteklasselærere gir uttrykk for at barn kjeder seg når de starter på sfo. Det hevdes at barna "opplever et vakuum" før skolestart og at "de går og venter". Samtidig ligger det noen erkjennelser i uttalelsene hos de pedagogiske lederne da de ser at de selv er med på å skape barnas forventninger. En slik erkjennelse kommer til uttrykk her:

Vi har glemt å snakke om sfo. De ble sjokkert av sfo da de trodde at det var skolen de skulle på.

Uttalelsen fra pedagogiske leder belyser, slik vi ser det, betydningen av kunnskap om sfo. En unders $\varnothing$ kelse fra Sverige (Johansson, 2007), der skolefritidsordningen er definert som en pedagogisk virksomhet, viser at de fleste av barna vil være på fritidshjemmet fremfor hjemme etter skoletid. Barna gir positiv omtale av fritidshjemmet, og deres uttalelser er knyttet til forhold som; mer lekemateriell, et større leketilbud og flere å være sammen med. Læringen knyttes til mer uformell læring og til sosial kompetanse. De sier at de lærer å være en god venn. De sosiale ferdigheter barna lærer i sfo overføres til hjemmearenaen, til leken i gata. Undersøkelsen (Johansson, 2007) viser at sammenhengen mellom de ulike arenaene er like viktig for barnet som erfaringene de gjør på hver enkelt arena.

\section{Betydningen av kommunikasjonsmessig kontinuitet}

Kunnskap om de ulike arenaene forutsetter en form for kommunikasjon. Kommunikasjonsmessig kontinuitet kan sikres på ulike måter, som gjennom felles faglige møter, gjennom å lese hverandres planer eller gjennom å observere hverandres pedagogiske praksis. Vi ønsket å unders $\emptyset$ ke vektleggingen av slike tiltak.

\section{Betydningen av felles faglige møter}

Resultatene fra spørreskjemaet viser at omtrent halvparten av respondentene oppfatter betydningen av faglige møter og hospitering i hverandres virksomheter som ikke eller mindre viktig (se tabell 7). Når det gjelder sfo, så er det over to tredjedeler $(67,4 \%)$ av respondentene som mener at dette er ikke eller mindre viktig. Dette er noe overaskende funn sett i lys av at noen pedagogiske ledere i spørreskjemaets åpne spørsmål gir uttrykk for at de gjerne vil gi informasjon til skolen om barnehagens satsingsområder og prosjekter barna har deltatt i. Man kan anta at felles faglige møter kunne være en hensiktsmessig arena for å formidle dette. 
Tabell 7. Betydning av møter og observasjon av hverandres praksis $(n=43 / 42)$.

\begin{tabular}{|c|c|c|c|c|c|c|c|c|}
\hline & \multicolumn{2}{|c|}{ ikke viktig } & \multicolumn{2}{|c|}{ mindre viktig } & \multicolumn{2}{|c|}{ ganske viktig } & \multicolumn{2}{|c|}{ meget viktig } \\
\hline & $\mathrm{n}$ & $\%$ & $\mathrm{n}$ & $\%$ & $\mathrm{n}$ & $\%$ & $\mathrm{n}$ & $\%$ \\
\hline $\begin{array}{l}\text { Viktighet av at ped.-leder, sfo- } \\
\text { leder og lærer har felles faglige }\end{array}$ & 8 & $19,0 \%$ & 13 & $31,0 \%$ & 13 & $31,0 \%$ & 8 & $19,0 \%$ \\
\hline lærer & 5 & $33,3 \%$ & 5 & $33,3 \%$ & 4 & $26,7 \%$ & 1 & $6,7 \%$ \\
\hline pedagogisk leder & 3 & $14,3 \%$ & 6 & $28,6 \%$ & 7 & $33,3 \%$ & 5 & $23,8 \%$ \\
\hline sfo-leder & 0 & $0,0 \%$ & 2 & $40,0 \%$ & 2 & $40,0 \%$ & 1 & $20,0 \%$ \\
\hline \multicolumn{9}{|l|}{$\begin{array}{l}\text { Viktighet av møtet mellom den } \\
\text { enkelte bhg og sfo for }\end{array}$} \\
\hline lærer & 3 & $20,0 \%$ & 9 & $60,0 \%$ & 2 & $13,3 \%$ & 1 & $6,7 \%$ \\
\hline ped-leder & 2 & $10,0 \%$ & 12 & $60,0 \%$ & 1 & $5,0 \%$ & 5 & $25,0 \%$ \\
\hline sfo-leder & 0 & $0,0 \%$ & 2 & $33,3 \%$ & 3 & $50,0 \%$ & 1 & $16,7 \%$ \\
\hline $\begin{array}{l}\text { Viktigheten av at ped-leder og } \\
\text { lærer observerer hverandres } \\
\text { praksis }\end{array}$ & 7 & $17,1 \%$ & 20 & $48,8 \%$ & 10 & $24,4 \%$ & 4 & $9,8 \%$ \\
\hline $\begin{array}{l}\text { Viktigheten av at ped-leder og } \\
\text { sfo-leder observerer hverandres } \\
\text { praksis }\end{array}$ & 9 & $21,4 \%$ & 23 & $54,8 \%$ & 8 & $19,0 \%$ & 2 & $4,8 \%$ \\
\hline
\end{tabular}

Svarfordelingene som er gjengitt i tabell 7 gir et generelt inntrykk av at faglige møtearenaer mellom de ulike partene ikke prioriteres i særlig høy grad. Men også når det gjelder dette temaet endrer bildet seg tydelig i forløpet av fokusgruppene. Behovet for faglige møter kommer til uttrykk på flere måter og er den kategorien som vies størst grad av oppmerksomhet i intervjuene. Informantene gir uttrykk for at de vet for lite om hverandre. I et intervju gir en pedagogisk leder klart uttrykk for savnet av faglig samarbeid:

Det jeg savner er et samarbeid, litt faglig utveksling ... Altså en samtale for dere får førsteklassingene, litt faglig utveksling. Eller kanskje året før vi begynner med skolestarterne, at vi vet hva skal vi egentlig legge vekt på, hva er viktig, hva synes dere er viktig? Så dere også får litt innsyn i hva vi driver med. Det har jeg lyst til.

Ulike uttalelser fra intervjuene kan forstås som et $\emptyset$ nske om å skape større grad av filosofisk kontinuitet for barna i overgangen fra barnehage til skole og sfo. Filosofisk kontinuitet kan skapes gjennom å vite mer om innhold og arbeidsmetoder i institusjonene, om læringens hva og hvordan. En førsteklasselærer sier: 
Det er også nyttig å vite hva seksårsgruppa i barnehagen har jobbet med. For det er veldig viktig for oss i skolen å gripe tak $i$. Det kom 25 stykker fra (...) og det hadde vort interessant å se hvilke temaer de har vart gjennom det siste barnehageåret. Akkurat det punktet mangler litt...

Noen av informantene forklarer mangel på filosofisk kontinuitet med færre lærerressurser i skolen. I motsetning til på 1990-tallet og begynnelsen på 2000-tallet arbeider ikke lenger førskolelærere og lærere sammen med de yngste barna på skolen. En førsteklasselærer uttaler:

... det å vite noe om hverandre, det var kanskje ikke så viktig før som det er nå. For da hadde man jo både forskolelarer og larer...

En pedagogisk leder responderer umiddelbart: Ja, og da hadde det vart mer lek.

Uttalelsene kan ses i sammenheng med at samarbeidet mellom barnehage og skole ble svekket etter 6åringenes inntog i skolen. Gjennom at førskoletilbudet ble gitt på skolen, overtok skolen i 1997 ansvaret for skoleforberedelsen (Hogsnes, 2010). I dag er barnehagelæreres adgang til arbeid i skolen begrenset. I følge Haug (2013) er tanken om å inkludere barnehagepedagogikken i dagens skole lite fremtredende. Skole har blitt mer skole, og leken har fått en underordnet betydning (Haug, 2013, s. 123). En av årsakene for utviklingen hevdes å være behovet for å legitimere den store satsingen på full barnehagedekning. Barnehage for alle barn skal gi bedre skoleprestasjoner. En følge av denne argumentasjonen kan være at samarbeid i mange kommuner forstås som "etablering av rutiner for overgangen" og "overføring av informasjon om enkeltbarnets kunnskaper og ferdigheter" (Haug, 2013).

Ettersom barn kan ha problemer med å overføre sin kompetanse fra barnehage til skole og sfo, kan de i stor grad forandre seg når de begynner på skolen (Broström, 2009). Vi ønsket derfor å se nærmere på vektleggingen av informasjon om enkeltbarn og hvilken form for deltakelse ulike parter, som lærere i barnehage, skole, sfo-medarbeidere, foreldre og barn, kunne ha i informasjonsutvekslingen.

\section{Informasjon fra barnehagen}

Resultatene fra spørreundersøkelsen vi gjennomførte, viser at møter der barnehagen gir informasjon om enkeltbarn vurderes som meget viktig av alle grupper, og det anses også som meget viktig at informasjon om enkeltbarn gis i form av skriftlig dokumentasjon.

Tabell 8. Betydningen av å formidle informasjon om enkeltbarn fra barnehagen til skolen $(n=43)$.

\begin{tabular}{|c|c|c|c|c|c|c|c|c|}
\hline & \multicolumn{2}{|c|}{ ikke viktig } & \multicolumn{2}{|c|}{ mindre viktig } & \multicolumn{2}{|c|}{ ganske viktig } & \multicolumn{2}{|c|}{ meget viktig } \\
\hline & $\mathrm{n}$ & $\%$ & $\mathrm{n}$ & $\%$ & $\mathrm{n}$ & $\%$ & $\mathrm{n}$ & $\%$ \\
\hline $\begin{array}{l}\text { Viktigheten av at det } \\
\text { gjennomføres møter der bhg'n } \\
\text { informerer om enkeltbarn }\end{array}$ & 1 & $2,3 \%$ & 1 & $2,3 \%$ & 7 & $16,3 \%$ & 34 & $79,1 \%$ \\
\hline
\end{tabular}


En svakhet ved undersøkelsen er at spørsmålene er formulert på en slik måte at svarene ikke forteller hvorvidt tiltakene vurderes som viktige for alle barn eller kun for noen barn. Svarene i intervjuene bekrefter samtidig i stor grad fokuset på enkeltbarnet. I en skolekrets er det avtale om at tiltaket skal gjelde for alle barn. Gjennom tiltaket søkes det å gi og motta informasjon som "gir skolen mulighet for å møte hvert barn på best mulig måte".

I intervjuene er det betydningen av informasjon om barn som "lett kan bli oversett" som anses som særlig viktig. En førsteklasselærer sier:

Egentlig bør vi bruke mer tid på de som kan forsvinne litt. De som ikke har så lett for å knytte sosiale kontakter. Det er de som er mest utfordrende for oss. Det er viktig å vare litt oppmerksom på disse på forhånd. Vi vil jo gjerne se alle og gi alle en best mulig start.

Det er i stor grad informasjon av sosial og relasjonell karakter som løftes fram, også av pedagogiske ledere. Til tross for at informasjon om enkeltbarn, også i form av skriftlig dokumentasjon, i stor grad ble vektlagt i spørreundersøkelsen, blir denne form for informasjon noe problematisert i intervjuene. En pedagogisk leder sier:

Det skjema er jo en start. Men, jeg kaller det ikke et samarbeid ... Det er bare overlevering av noen ord på et ark. Det er ikke noe kommunikasjon. Det er en monolog fra oss til skolen. ... Det er ikke spørsmål om noen av skjemaene som er fylt ut og sendt inn. Jeg lurer på; blir de brukt? Jeg tenker at dette kommer til å bli sett kjapt på. Bortsett fra det punktet om ressurser som må følge med ...

Ingen av førsteklasselærerne kan gi et klart svar på hvordan skriftlig dokumentasjon om barn blir benyttet i skolen. Dette kan ha ulike årsaker. En av 1.klasselærere kom fra 7. trinn og hadde ingen erfaring med tiltaket. Det synes likevel som om informantene er mer positivt innstilte til den muntlige informasjonsutvekslingen enn den skriftlige.

\section{Informasjon fra foreldre}

En unders $\varnothing$ kelse fra Sverige viser at foreldre og pedagoger ofte gir ulike beskrivelser av de samme barna (Pramling Samuelsson og Sheridan, 2008). Hvem som informerer og om hva kan dermed ha stor betydning for førsteklasselæreres og sfo-lederes møte med enkeltbarnet. Vi finner relativt stor variasjon i svarene på spørsmål vedrørende betydningen av kommunikasjon med foreldre i overgang fra barnehage til skole og sfo. På spørsmålet om betydningen av at førsteklasselærer inviterer hvert barn med foreldre sammen til samtale før skolestart, svarer nesten halvparten av de pedagogiske lederne at dette er viktig. Ingen av lærerne, og kun en av sfo-lederne deler denne vurderingen. Tiltaket ses som mindre og ikke viktig. Det kan synes som om formaliserte samtaler om enkeltbarn, både med foreldre og med foreldre og barn sammen, ikke tillegges særlig betydning for å skape en god overgang og sammenheng mellom barnehage og skole.

Støtte fra hjemmet er, i følge barn selv, viktig i overgangen (OECD, 2006, s. 69). En undersøkelse konkluderer imidlertid med at dette er et område med behov for mer forskning. Det er behov for at lærere vet mer om barnets hjemmesituasjon og at foreldre vet mer om barnas liv i institusjonene (Clarke, 2007). Svarene fra vår spørreundersøkelse og fokusgruppeintervjuene tyder på at foreldre er deltakende i utarbeidelse av informasjonsskrivet om barnet, men at det er pedagogene som prioriteres i dialogen om overgangen. Et spørsmål som reiser seg er hvordan foreldrene kan bidra mer aktivt i samarbeidet med å tilrettelegge for 
gode overganger og opplevelse av sammenheng mellom institusjonene. I fokusgruppeintervjuene kom det fram et eksempel på foreldres bidrag i informasjonsutvekslingen. En førsteklasselærer sier:

Vi prøvde noe nytt $i$ år, noe som vi har veldig god erfaring med. I lopet av de to forste ukene har vi oppstartsamtale med foreldre og oss kontaktlarere. Der skal ikke vi si noe om deres barn, men de skal fortelle oss hva de synes er viktig, ting vi skal ta hensyn til. Det har foreldre gitt veldig positive tilbakemeldinger på.

Eksempelet viser hvordan foreldre kan bidra gjennom å gjøre førsteklasselærer kjent med enkeltbarnets situasjon. Dette er vesentlig med tanke på at alle barn skal sikres en god overgang og opplevelse av sammenheng mellom institusjonene. Et ensidig fokus på enkeltbarnet, som ikke tar høyde for og anerkjenner et mangfold i barns hjemmemiljøer og tidligere erfaringer, kan virke svært ekskluderende (Vandenbroeck m.fl., 2013).

\section{Informasjon fra barna}

I dialogen med barna ligger muligheten for utvikling av nye ideer om hva som kan være viktig for barn i overgangen, om hva som kan bidra til opplevelse av sammenheng og hvordan barn kan delta aktivt i dette arbeidet. En form for aktiv deltakelse fra barn kan være at barna selv får presentere noe de har vært engasjert i i barnehagen.

Tabell 9. Betydningen av at barna selv kan få presentert noe i skolen som de har vært engasjert i i barnehagen $(n=43)$.

\begin{tabular}{|c|c|c|c|c|c|c|c|c|}
\hline \multicolumn{9}{|c|}{ Viktigheten av at barna selv får presentere noe de har vært engasjert i i barnehagen } \\
\hline & \multicolumn{2}{|c|}{ Ikke viktig } & \multicolumn{2}{|c|}{ mindre viktig } & \multicolumn{2}{|c|}{ Ganske viktig } & \multicolumn{2}{|c|}{ Meget viktig } \\
\hline & $\mathrm{n}$ & $\%$ & $\mathrm{n}$ & $\%$ & $\mathrm{n}$ & $\%$ & $\mathrm{n}$ & $\%$ \\
\hline Lærer & 3 & $20,0 \%$ & 6 & $40,0 \%$ & 5 & $33,3 \%$ & 1 & $6,7 \%$ \\
\hline Ped-leder & 2 & $11,1 \%$ & 4 & $22,2 \%$ & 10 & $55,6 \%$ & 2 & $11,1 \%$ \\
\hline Sfo-leder & 0 & $0,0 \%$ & 2 & $33,3 \%$ & 3 & $50,0 \%$ & 1 & $16,7 \%$ \\
\hline
\end{tabular}

I underkant av $70 \%$ av de pedagogiske lederne anser et slikt tiltak som viktig i spørreundersøkelsen. Flertallet av sfo-lederne deler de pedagogiske ledernes oppfatning, mens de fleste av førsteklasselærerne anser det som mindre viktig. Behovet for kommunikasjon synes, for respondentene, i stor grad å handle om informasjon om enkeltbarn. I intervjuene presenteres dette som et område flere ønsker å forbedre. En pedagogisk leder sier dette om informasjonen som gis til skolen i dag:

Det står ikke noe om hva barnet interesserer seg for og hvordan man skal bruke det i møte med barnet.

Pedagogisk leder viser til skjemaet som er utarbeidet i kommunen og etterspør en kommunikasjon som kan gi barn større mulighet for å framstå som aktive deltakere i arbeidet med å sikre sammenheng i 
overgangen. I de fleste barnehagene gjennomføres det samtaler med barna om deres forventninger og spørsmål vedrørende skolestart. I en av barnehagene ble barnas forventninger overlevert skolen i brevform. I en annen sendte barna, sammen med pedagogisk leder, spørsmålene sine til skolen via mail. Skolene var inviterende, og i noen tilfeller ble barns spørsmål etterfulgt av skolebes $\varnothing \mathrm{k}$ der barna fikk søke å finne svar på det de lurte på. En pedagogisk leder forteller om et møte for de eldste barnas foreldre i etterkant av skolebesøkene. I møtet er det barna som, gjennom å vise til egne dokumentasjoner, informerer foreldrene om hva de har fătt av kjennskap til skolen. Slike tiltak kan være gode eksempler på hvordan barn kan bidra aktivt i å skape sammenhenger mellom hjem, barnehage, skole og sfo.

\section{Oppsummering og noen tanker om fremtidig forskning}

Til tross for at funnene fra denne undersøkelsen ikke kan generaliseres, representerer de likevel et bidrag til forståelsen av hvordan ulike aktører vurderer hva gode overganger og sammenhenger kan være for barn. Ut fra vårt ståsted har undersøkelsen bidratt til å synligjøre hvordan ulike former for kontinuitet virker sammen og forutsetter hverandre. Med bakgrunn i våre forskningsspørsmål viser undersøkelsen en stor bredde og variasjon i tiltak som skal ivareta sammenheng og gode overganger, og videre at vurderingene, særlig fra barnehage- og skolelærerne, i stor grad er i overenstemmelse med hverandre. Dette kom spesielt til uttrykk i fokusgruppeintervjuene. Videre kan funnene leses slik at pedagogiske lederes, sfo-lederes og førsteklasselæreres prioriteringer av tiltak samlet sett dekker de fire formene for kontinuitet, fysisk, filosofisk, sosial og kommunikasjonsmessig kontinuitet, slik de er presentert i litteraturen (Broström, 2009; Fabian 2007). Etter vår vurdering har kontinuitetsformene vært nyttig som analytiske kategorier i arbeid med det empiriske materialet.

Svarene fra spørreundersøkelsen viser at alle grupper så det som særlig viktig at barna fikk bli kjent med skolens fysiske miljø før skolestart. Alle grupper la også stor vekt på opprettholdelse av og etablering av vennskap i overgangen. Dette er tiltak som kan kategoriseres under fysisk og sosial kontinuitet. Tiltak som kan sikre skolen kunnskap om enkeltbarn, ble også høyt prioritert av alle grupper i spørreundersøkelsen, mens tiltak som kunne bidra til filosofisk kontinuitet for barna i overgangen, ble ansett som mer utfordrende å gjennomføre. Det samme kan sies om den kommunikasjonsmessige kontinuiteten, som synes å være et viktig grunnlag for så vel fysisk, som sosial og filosofisk kontinuitet. I intervjuene var våre informanter mest opptatt av den kommunikasjonsmessige kontinuiteten. For å kunne ta hensyn til og forberede barna på deres fremtid, må barnehagen ha kunnskap om hva barna faktisk vil møte i skolen. For å kunne ta hensyn til barnas fortid, må skolen ha kunnskap om barns tidligere erfaringer i barnehagen (Broström, 2009). Mangel på kommunikasjon ble fremstilt som en hindring, spesielt med tanke på å få til større grad av filosofisk kontinuitet. Det lot til å være en generell oppfatning at det må prioriteres, organiseres og settes av tid til et mer reelt samarbeid og kommunikasjon. Fokusgruppeintervjuene fremsto i seg selv som en arena for denne typen etterspurt kommunikasjon. De ga informantene muligheten for å reflektere sammen og nyansere svarene fra spørreundersøkelsen. Å få vite mer om hva som hemmer og fremmer kommunikasjon under ulike betingelser i ulike kommuner bør bli gjenstand for fremtidig forskning. I følge våre informanter var det interesse for et tettere samarbeid.

Undersøkelsen har løftet fram flere perspektiver og spørsmål vi finner verdt å undersøke nærmere $\mathrm{i}$ fremtidige studier. Et sentralt emne er hvordan barn og foreldre kan bidra aktivt $\mathrm{i}$ arbeidet med å skape gode overganger og sammenhenger mellom barnehage, sfo og skole. I henhold til de 
Forente Nasjoners (FN) barnekonvensjon ${ }^{3}$ har barn rett til å bli inkludert som aktive deltakere i ulike aktiviteter på ulike arenaer. Unders $\emptyset$ kelser i Norge viser at barns aktive deltakelse fremstår som relativ beskjedent i skoleforberedende aktiviteter i barnehagen (Rambøll, 2010; Østrem m.fl., 2009), sammenlignet med barnehagens pedagogiske arbeidsmåter for $\varnothing v$ vig. Skal vi forstå noe om hvordan barn opplever sammenheng i overgangen fra barnehage til skole og sfo, må vi gå i dialog med barna. Hvordan barn selv kan bidra i arbeidet med å sikre gode overganger og opplevelse av sammenhenger mellom barnehage, sfo og skole er et område som fortsatt krever videre forsking.

Med tanke på at det har vært lite oppmerksomhet rettet mot sfo (Foss, 2011), kan det også være behov for å se nærmere på sfo's betydning for barn i overgangen. Et spørsmål vi stiller oss er om sfo's status som ikke-pedagogisk virksomhet i Norge, medfører at denne institusjonenes potensielle betydning for barna i overgangen fra barnehage til skole blir undervurdert? En komparativ undersøkelse av sfo's rolle og betydning i Norge, Sverige og Danmark, kunne således være interessant å gjennomføre for å få mer kunnskap om dette temaet.

\footnotetext{
${ }^{3}$ FN's konvensjon om barns rettigheter. Vedtatt av de forente nasjoner 20.november 1989, ratifisert av Norge 8.januar 1991
} 


\section{Referanser}

Birch, Sondra H. \& Ladd, Garry W. (1998). Children's interpersonal behaviors and teacher-child relationship. Developmental psychology, 34, 934-946.

Bjørnestad, Elisabeth (2005). Hvordan forstå tradisjonsmøte mellom barnehage og skole på 1. Trinn? Norsk Pedagogisk Tidsskrift, 89(5), 379-390.

Bratterud, Åse; Sandseter, Ellen-Beate H. \& Seland, Monica (2012). Barns trivsel og medvirkning $i$ barnehagen. Barn, foreldre og ansattes perspektiver. Rapport 21/2012. Skriftserie til barnevernets utviklingssenter Midt-Norge. Trondheim: NTNU samfunnsforskning.

Braun, Virginia \& Clarke, Victoria (2006). Using thematic analysis in psychology. Qualitative Research in Psychology, 3(2). 77-101.

Broström, Stig (2012). Børnehavens didaktikk, nu og i fremtiden. Institut for Uddannelse og Pædagogik (UDP): Aarhus universitet.

Broström, Stig (2009). Tilpasning, frigjøring og demokrati. Første steg, 2, 24-28.

Broström, Stig (2003). Farvel børnehave- hei skole. Undersøgelser og overvejelser. Århus: Systime.

Broström, Stig (2002). Kontinuitet og helhed i overgangen fra børnehave til skole. Barn, 1, 7-22.

Clarke, Christine (2007). Parent involvement in the transition to school. In Aline-Wendy Dunlop \& Hilary Fabian (Eds.), Informing transition in the early years. Research, policy and practice (pp. 120-136). Maidenhead: Open University Press, McGraw-Hill.

Dockett, Sue, \& Perry, Bob (2007). Childrens transition to school: changing expectations. I AlineWendy Dunlop \& Hillary Fabian (Eds.), Informing transition in the early years. Research, policy and practice (s. 92-104). Maidenhead: Open University Press, McGraw-Hill.

Dunlop, Aline-Wendy \& Fabian, Hilary (Eds.) (2007). Informing transitions in the early years. Research, policy and practice. Maidenhead: Open University Press, McGraw-Hill.

Eide, Brit-Johanne \& Winger, Nina (1994). "Du gleder deg vel til å begynne på skolen!'. Oslo: Barnevernsakademiet.

Fabian, Hilary (2007). Informing transitions. I Aline-Wendy Dunlop \& Hilary Fabian (Eds.), Informing transitions in the early years. Research, policy and practice (pp. 3-17). Maidenhead: Open University Press, McGraw-Hill.

Foss, Vigdis (2011). Usynlige læringskulturer i skolefritidsordningen. Barn, 2, 27-46.

Germeten, S. (2002). Grenser for undervisning? Frihet og kontroll i 6-åringenes klasserom. Doktoravhandling, Lärarhögskolan i Stockholm, HLS förlag, Stockholm.

Haug, Peder (2013). From indifference to invasion: The relationship from a Norwegian perspective. In Peter Moss (Ed.). Early childhood and compulsory education. Reconceptualising the relationship (pp. 112-129). London \& New York: Routledge.

Haug, Peder (1994). Skolefritidsordningene, bakgrunn og utvikling. I Hilde Lidèn, Anne Øie \& Peder Haug (Red.), Mellom skole og fritid (s. 13-27). Oslo: Universtitetsforlaget.

Hogsnes, Hilde Dehnæs (2010). Læring og sammenheng mellom barnehage og skole. I Hilde D. Hogsnes, Mona-Lisa Angel \& Solveig Nordtømme (Red.), Barnehagens laeringsliv. Bergen: Fagbokforlaget.

Jansen, Turid Thorsby (2000). Barnehage, - Verken eller? Om barnehagens egenart. HiOrapport nr 10. Oslo: Høgskolen i Oslo.

Jensen, Anders Skriver, Hansen, Ole-Henrik \& Broström, Stig (2013). Contemporary Danish perspectives: Towards a new paradigm. In Kay Margretts \& Anna Kienig (Eds.), International perspectives on transitions to school: Reconceptualising beliefs, policy and practice (Chapter 5). London \& New York: Routledge. 
Johansson, Eva \& Pramling Samuelsson, Ingrid (Red.) (2003). Förskolan: barns första skola! Lund: Studentlitteratur.

Johansson, Inge (2007). Horizontal transitions; what can it mean for children in the early school years? In Aline-Wendy Dunlop \& Hilary Fabian (Eds.), Informing transition in the early years. Research, policy and practice (pp. 33-44). London: Open University Press.

Kirke-, utdannings- og forskningsdepartementet (KUF) (1997). St.meld. $n r$. 55. (1996-1997). Om skolefritidsordningen. Oslo: Kirke-, utdannings- og forskningsdepartementet.

Kunnskapsdepartementet (KD) (2011). Rammeplan for barnehagens innhold og oppgaver. Oslo: Kunnskapsdepartementet.

Kunnskapsdepartementet (KD) (2009). St. meld. nr. 41 (2008-2009). Gode barnehager for alle. Stortingsmelding om kvalitet i barnehagen. Oslo: Kunnskapsdepartementet.

Kunnskapsdepartementet (KD) (2008). Fra eldst til yngst. Samarbeid og samanheng mellom barnehage og skole. Veileder. Oslo: Kunnskapsdepartementet.

Kunnskapsdepartementet (KD) (2006). Fastsatte lareplaner for Kunnskapsløftet. Oslo: Kunnskapsdepartementet.

Kvale, Steinar (1997). Det kvalitative forskningsintervju. Oslo: Ad.notam Gyldendal.

Leech, Nancy L. \& Onwuegbuzie, Anthony J. (2009). A typology of mixed methods research designs. Quality \& Quantity, 43(2), 265-275.

Lidèn, Hilde (1994). Barns perspektiv - de voksnes utfordring? I Hilde Lidèn, Anne Øie \& Peder Haug (Red.), Mellom skole og fritid (s. 28-57). Oslo: Universitetsforlaget.

Margetts, Kay \& Kienig, Anna (Eds.) (2013). International Perspectives on Transition to School. Reconceptualising beliefs, policy and practice. London \& New York: Routledge.

Maxwell, Joseph, A. (2005). Qualitative research design: an interactive approach. Thousand Oaks: Sage.

OECD (2001). Starting strong: Early childhood education and care. Paris: Organisation for Economic Co-operation and Development.

OECD (2006). Starting Strong II: Early childhood education and care. Paris: Organisation for Economic Co-operation and Development.

Persson, Sven \& Vetenskapsrådet (2008). Forskning om villkor för yngre barns lärande i förskola, förskoleklass och fritidshem. Stockholm: Vetenskapsrådet.

Peters, Sally (2010). Literature Review: Transition from Early Childhood Education to School. Report to the Ministry of Education. Wellington: Ministry of Education, New Zealand.

Pramling Samuelsson, Ingrid \& Sheridan, Sonja (2008). Play and learning in Swedish early childhood education. In Ingrid Pramling Samuelsson \& Marilyn Fleer (Eds.), Play and Learning in Early Childhood Settings: International Perspectives (Vol. 1, p. 135-154). Milton Keynes: Springer.

Rambøll Management (2010). Kartlegging av det pedagogiske innholdet i skoleforberedende aktiviteter i barnehager. Oslo: Rambøll.

Skolverket (2010). Perspektiv på barndom og barns lärande. En kunnskapsöversikt om lärande $i$ förskolan och grundskolans tidigare år. Stockholm: Skolverket.

Stake, Robert E. (2005). Qualitative case studies. I Norman K. Denzin \& Yvonne. S. Lincoln (Eds.), The sage handbook of qualitative research. (pp. 443-466). London: Sage.

Søbstad, Frode (2002). Jaktstart på kjennetegn ved den gode barnehagen. Første rapport fra Prosjektet "Den norske barnehagekvaliteten". Trondheim: DMMHs publikasjonsserie nr. 2:3536. 
Thomas, Gary (2011). A typology for the case study in social science following a review of definition, discourse and structure. Qualitative Inquiry, 17(6), 511-521.

Vandebroeck, Michel; De Stercke, Nadine \& Gobeyn, Hildegard (2013). What if the rich child has poor parents? The relationship from a Flemish perspective. I Peter Moss (Eds), Early childhood and compulsory education. Reconseptualising the relationship (pp.174-191). London $\&$ New York: Routledge.

Wibeck, Victoria (2000). Fokusgrupper. Om fokuserade gruppintervjuer som undersökningsmetod. Lund: Studentlitteratur.

Østrem, Solveig, Bjar, Harald, Føsker, Line I., Hogsnes, Hilde Dehnæs, Jansen, Turid Thorsby, Nordtømme, Solveig \& Tholin, Kristin Rydjord (2009). Alle teller mer. En evaluering av hvordan rammeplan for barnehagens innhold og oppgaver blir forstått, brukt og erfart. Tønsberg: Høgskolen i Vestfold. 